sammengestoppelt" charakterisiert), mit dem man in einem Land mit einer Bevölkerungsdichte von de facto 1500 Personen pro qkm (Bundesrepublik 351 pro qkm) eine drohende Zersiedelung des knappen Bodens verhindern und einen geordneten Städtebau gewährleisten will. Den Unterschied in der Stadtproblematik zwischen Industrie- und Entwicklungsländern zeigt Cortiñas-Pelães: Landflucht und Wildwuchs der Städte in letzteren ließen kein wirksames Städtebaurecht zu. Raumplanung und Städtebaupolitik seien undurchführbar (S. 451). Karol Gandor, Kattowitz, und Karol Sobczak, Warschau, geben eine Übersicht über verwaltungsrechtliche Mittel des Verbraucherschutzes in Polen. Dieser ist im Unterschied zur westlichen Auffassung offenbar dadurch gekennzeichnet, daß nicht der ,Verbraucher als Person auf dem Markt" im Vordergrund steht, sondern die ,Sicherung des umfassenden Angebots von Waren und Dienstleistungen“" (S. 465).

Der vorliegende Band, in dessen Einzelbeiträgen ein anerkennenswert gründliches Spezialwissen zu mit glücklicher Hand ausgewählten Themen verarbeitet ist, enthält einen international breiten Querschnitt von großer Aktualität und leistet damit einen gewichtigen Beitrag zur Rechtsvergleichung im öffentlichen Recht. Er ist gleichzeitig ein Dokument der hervorragenden Tätigkeit der AvH und ihrer Mitarbeiter. Zu bedauern ist, daß in einem Buch, dem eine internationale Verbreitung bestimmt und das auch ein Aushängeschild der Stiftung ist, sich eine Reihe vermeidbarer Druckfehler finden, die das Maß des Ublichen überschreiten.

Jürgen Becker

\title{
FRANK BARTON:
}

\section{The Press of Africa: Persecution and Perseverence.}

African Publishing Company, 1979, 304 S.

In this book, Frank Barton writes about people and not things. He writes about people who have done and who do things. He dwells on people who with lots of difficulties launched the press in troubled Afrika. People who hijack the smooth running of the press to serve on their private railroads. People who fight to keep a newspaper a newspaper, and people who simply commit a coup de grace on the press in an Africa dominated by Black power aspirations and extreme White injustices.

The book begins with a lamentation of a journalist - ,,As political freedom came to the Continent, he did press freedom disappear" (see page IX). Barton carries the reader through the historical background of the press in Africa, starting from West Africa, and south of the Sahara, down to the Cape. He examines at close range the development of the press in Anglophone, Francophone and Portuguese African countries in their pre and past independence status. There is also a convincing attempt to examine the development of the press in Africa, particularly West Africa, in the pre-colonial days. A careful analysis of the press in the two ,,unconquered countries" and the ,,long time Christian States" in Africa (Liberia and Ethiopia) is successfully made.

The approach to the subject, based mainly in African press activities, in independent Africa (apart from South Africa and Namibia) is on historical development. The question of the freedom of the press and the position of the newsman, who walks on very slippery ground, is carefully examined. By all means the 304 page book is a factual work reflecting an intensive research on one of the most sensitive issue to African politicians and elites. The book is a servicebook on the related issues in a perfect way.

The book has, however, its shortcomings. There are moments when the writer jails to penetrate the African mind, to reason like an African (he is not of course) and to see things in the African perspective. These are the necessary elements in order to treat such a subject with a 
great measure of justice. Barton looks at Africa, with its troubled press from a European microscope and only fails short of making European judgments by embarking on general, sometimes convincing, reflections and excuses for the press situation in Africa. This position is a bit too light because Barton remains, throughout the book, a western trained journalist cherishing tenderly western ideals and values about the press and wishing to see these elements effectively sown and let to grow with whatever development of the press in Africa. The press is a new ,,mass media“ in Africa, and Barton knows of that. However, this is not apparently a true mass media. It remains largely an elite-media because up to now the press has not managed to reach the grassroots of the African society. It remains basically a foreign good concept alright, but still a foreign material, from the way it carries its principles, the languages used to the nature of education or training preserved by the people behind newspaper business. This is mainly a very small minority class of educateds in countries where more than ninety percent of the population can neither read nor write let alone understand English, French or Portuguese. In these circumstances you are of great value to the Journalist if you can read and you are useless if you cannot, although of course your illiterate status would be for him a speculative issue for another article advising on a campaign against illiteracy. It is a few literate people who would read his mind. The paper and the journalist remain, in Africa, town dwellers, and detached from the villages.

It is true as Barton indicates, that the press had played one of the leading roles in Uhuru struggles in Africa. Its role today can be doubted a bit much as it still carries the same importance. Its importance is based on the fact that the minority elites or middle class men who use this powerful vehicle to bring about changes in the countries tend to rely on it as a corrective measure. It thus needs considerable measures of independent movements - reasoning. Still one can doubt the exclusive role of the press in Africa, especially where it remains detached from the grassroots, and has tended to be a tool for the struggles of the middle classes in pursuing their divergent interests and ideals, purporting to be representative of the wishes of the ,people“.

Freedom of the press is an important issue alright, but not always is such a freedom constructive, especially in African countries where nationhood is in very infant stages and that such freedoms falling into wrong pens would halt a major step toward the creation of truly united nations by serving seeds of discard among the people etc. The curbing of such freedoms could be a reflection of what the African politician wants the press to be. Should it carry the western concept or should it be a vehicle for social, political and economic awareness and development? It becomes imperative to understand first and foremost the nature of the African political situations and aspirations at length and the social fabrics of the African societies in order to make a just conclusion. Persecution and perseverence would then reflect something if they were to be examined in this light. Indeed a lot has bien written on the African press etc. from Europe. It is important, for instance, to read Henryka Schabowska and Ulf Himmelstrand in their ,,Africa Reports on the Nigerian Crisis. News, Attitudes and Background information", a book which received review from Kunig in VRU 12 (1979) p. 71.

The book deserves merits of its own kind. Barton being a journalist has displayed a pressional touch in the work, and the treatment of the usually vague and complicated issue is put in a simple clear and gripping language reflecting at times journalistic humour. It is in itself a must-textbook for the student of journalism in Black Africa; and a valuable assets to journalists and other people interested in the question of the freedom of the press in Africa.

Costa R. Mahalu 